\title{
Effect of retinoic acid in lichen planus of the genitalia and perianal region
}

\author{
S. GÜNTHER \\ Department of Dermatology, University of Glasgow
}

Lichen planus of the male genitalia presents as multiple violaceous papules or discrete annular lesions on the glans or shaft of the penis. In female patients, whitish striae or "leukoplakia-like" patches are occasionally observed on the vestibulum or labia minora and bluish-white papules in the anal cleft or around the anus. Signs of lichen planus elsewhere on the body may be absent.

As has been noted in lichen planus of the oral mucosa, lesions of the genitalia and perianal region tend to persist for years. Several therapeutic remedies have been tried with no material benefit. Only the more concentrated fluorinated local corticosteroids have appeared to cause resolution of the lesions, but the results are not permanent and recurrences are frequent as soon as the therapy is withdrawn. When retinoic acid is used in lichen planus of the skin or oral cavity, resolution has been observed (Günther, 1971, 1972a, b, 1973). It was therefore proposed to study the effect of retinoic acid (vitamin A acid) on lichen planus lesions of the genitalia and perianal region.

\section{Investigations}

Seven patients suffering from typical lichen planus were included in the trial: four men with annular or papular lesions on the glans penis and three women with bluishwhite papules in the anal cleft or around the anus. Two of the women also had whitish patches or striae on the labia minora. In five of the seven patients, treatment was started within the first 3 months of the development of the skin lesions, but one man had had annular penile lesions for $5 \frac{1}{2}$ years and one woman had had lesions in the anal region for 8 months. None had received any previous treatment.

Topical therapy with retinoic acid 0.1 per cent. in orabase (sodium carboxymethylcellulose, pectin, and gelatin in a liquid paraffin-polythene base) was applied to the genitalia or anal region once in 24 or $48 \mathrm{hrs}$ at night

Received for publication March 23, 1973.

Address for reprints: Prof. S. Günther, M.D., D.Sc., Ph.D., University of Glasgow, Department of Dermatology, 56 Dumbarton Rd, Glasgow G11 6NU, Scotland and removed the next morning. Systemic therapy consisted of hard gelatin capsules, containing $10 \mathrm{mg}$. retinoic acid and $90 \mathrm{mg}$. glucose, taken three or four times a day. The patients were examined daily. Liver function tests, transaminases, blood count, and urine were checked before and at the end of therapy.

\section{Results}

The topical administration of retinoic acid was most effective in annular or papular lichen planus of the glans penis; the lesions showed complete involution after 2 to 3 days and therapy could then be stopped (Figs 1 to 3, overleaf).

Recurrence was noted in one patient 6 months after withdrawal of treatment, but the lesions again responded promptly to the same short course of retinoic acid. The four men were observed for 9,13 , 14 , and 17 months respectively.

In lichen planus of the anal cleft, perianal region, or labia minora, topically applied retinoic acid was less satisfactory, and the treated areas became inflamed and irritable. More satisfactory results were obtained when retinoic acid was given orally; the lesions disappeared within 3 weeks, but one woman showed an increase in the serum transaminase (SGPT) to 49 Frankel units per $\mathrm{ml}$. (normal range 5 to 35 ). In the other women the results of laboratory tests remained within normal limits.

The three women were observed for 10,12 , and 12 months respectively and no recurrence was observed.

\section{Summary and conclusion}

Lichen planus lesions of the genitalia and perianal region tend to persist for years and are highly resistant to all known therapeutic procedures. Although topical corticosteroids may result in improvement, this is usually only temporary.

Seven patients with lichen planus lesions on the genitalia or perianal region were treated with retinoic 


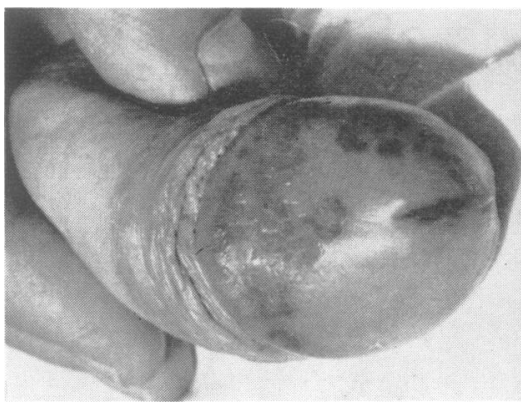

FIG. 1 Annular and papular penile lichen planus lesions, before treatment

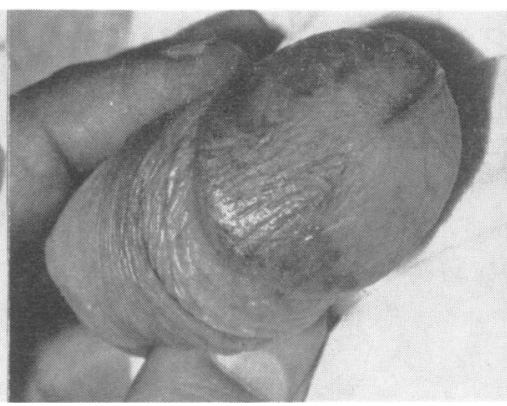

FIG. 2 The same patient as in Fig. 1, after 2 days of topical treatment with retinoic acid

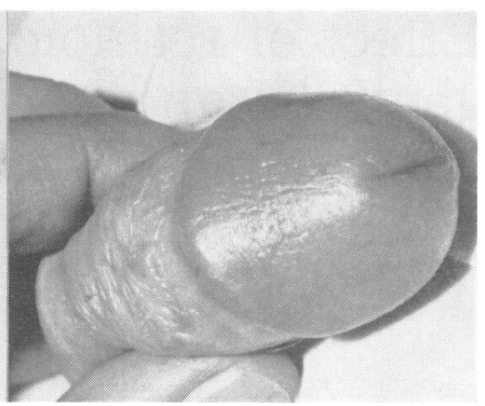

FIG. 3 The same patient 1 week after withdrawal of the 2 days' topical treatment with retinoic acid acid (vitamin A acid). In annular or papular lesions of the glans penis, topical administration of retinoic acid 0.1 per cent. in orabase resulted in complete involution after 2 to 3 days. In lichen planus of the labia minora or perianal region, local application was unsatisfactory, but retinoic acid given systemically resulted in marked clinical improvement.

My thanks are due to the consultants at the Skin Department of the Western Infirmary, Glasgow, for referring patients to me. Special thanks go to Dr. W. N. Morley for his interest and co-operation.

\section{References}

GüNTHER, S. H. (1971) Dermatologica (Basel), 143, 315 (1972a) Ibid., 145, 344

(1972b) Bull. Soc. franç. Derm. Syph., 79, 477

(1973) Arch. Derm. (Chicago), 107, 277
Effet de l'acide rétinoique dans le lichen plan des régions génitales et péri-anales

\section{SOMMAIRE}

Les lésions de lichen plan des régions génitales et périanales ont tendance à persister pendant des années et a être résistantes à tous les procédés thérapeutiques connus quoique l'application locale de corticostéroides puisse apporter une amélioration qui est, généralement, seulement temporaire.

Sept malades ayant des lésions de lichen plan sur les régions génitales et péri-anales furent traités par l'acide rétinoïque (acide vitaminique $\mathrm{A}$ ). Dans les lésions annulaires ou papulaires du gland, l'application locale d'acide rétinoïque à 0,1 pour cent dans l'orabase, amena une régression complète après 2 à 3 jours. Dans le lichenplan des petites lèvres ou de la région péri-anale, l'application locale ne fut pas satisfaisante, mais l'acide rétinoíque donné par voie générale permit une amélioration clinique marquée. 